\title{
Terroryzm w obliczu bezpieczeństwa państwa
}

\begin{abstract}
Nie można też nie dostrzegać innej bolesnej plagi dzisiejszego świata: zjawiska terroryzmu, nastawionego na zabijanie i niszczenie bez różnicy ludzi i dóbr, na tworzenie klimatu strachu i niepewności, często również poprzez więzienie zakładników.
\end{abstract}

Jan Paweł II, Encyklika Sollicitudo Rei Socialis

\section{Wprowadzenie}

Europa po długim okresie względnego bezpieczeństwa ponownie walczy z poważnymi zagrożeniami. Po opanowaniu kryzysu gospodarczego, który dominował w ostatnich latach, doszło do naruszenia integracji Europy, za czym stoi m.in. fala migracji, która spowodowała uaktualnienie wielu kwestii dotyczących istotnych zagrożeń społecznych, politycznych, kulturowych, humanitarnych, a wraz z nimi spraw bezpieczeństwa. Po prawie dwóch dekadach pokoju w Europie znowu doszło do wybuchu konfliktu zbrojnego, aneksji terytorium suwerennego państwa. Na peryferiach Europy czy w bezpośrednim sąsiedztwie w ostatnich latach sytuacja dramatycznie pogorszyła się we wszystkich aspektach bezpieczeństwa, w tym w aspekcie militarnym. Po latach Unia Europejska ma do czynienia ze skomplikowaną sytuacją międzynarodową i potencjalnym zagrożeniem militarnym. Sytuacja w zakresie bezpieczeństwa w Europie przekłada się również na Polskę.

W niniejszym artykule dokonano analizy istoty terroryzmu jako zagrożenia bezpieczeństwa w szczególności w odniesieniu do Polski. Chcąc utrzymać odpowiedni poziom bezpieczeństwa społeczeństwa, powinniśmy analizować spektrum zagrożeń, przed którymi stoi cały nasz kontynent. Zewnętrzne warunki bezpieczeństwa 
nie dotyczą tylko tradycyjnych kwestii, takich jak ekstremizm i radykalizm, lecz są również powiązane z przestępczością zorganizowaną, która jest obecnie w skali europejskiej poważnym problemem. Ocena zagrożeń nie powinna dotyczyć tylko samej ich identyfikacji, lecz powinna obejmować również ich skutki uboczne, które przecież nie pozostają bez wpływu na poziom bezpieczeństwa ${ }^{1}$. Mimo iż negatywny wpływ ataków terrorystycznych na poziom bezpieczeństwa jest mniejszy niż oddziaływanie całego spektrum przestępstw popełnianych w ciągu roku w Unii Europejskiej, nie można wszakże terroryzmu bagatelizować.

\section{Zagrożenie terrorystyczne}

W dzisiejszych czasach zagrożenia systemu bezpieczeństwa wewnętrznego mogą okazać się narzędziem walki politycznej. W ostatnich latach obserwuje się wzrost aktywności populistycznych i ekstremistycznych grup politycznych, które — jak terroryści - rozpowszechniają nienawiść i strach, a oferują proste i radykalne rozwiązania. Społeczne, gospodarcze, psychologiczne i polityczne następstwa ataków terrorystycznych znacznie wpływają więc na przekształcanie obrazu bezpieczeństwa społecznego; wraz z pojawieniem się tzw. Państwa Islamskiego $(\text { ISIS })^{2} \mathrm{i}$ innych grup terrorystycznych następuje destabilizacja w niektórych krajach Bliskiego Wschodu i Afryki Północnej.

Terroryzm możemy zdefiniować jako zachowanie, które jest ideologicznie, politycznie i religijnie motywowane, a polega na stosowaniu przemocy i gróźb w celu wywołania przede wszystkim strachu ${ }^{3}$. Na zagrożenie terroryzmem w obecnych czasach nie jest odporny żaden kraj, łącznie z Polską. Jednocześnie zagrożenia radykalnym Islamem z powodów historycznych i demograficznych znacznie częściej występują w Europie Zachodniej niż w Europie Środkowej.

Współczesny terroryzm ma wiele źródeł, większość z nich ma swoje korzenie poza granicami krajów, które stają się celem ataków ekstremistów. Dla rządów poszczególnych państw bardzo ważne jest, aby ocenić obecną gotowość i zdolność do zapobiegania działalności terrorystycznej na własnym terytorium w celu ograniczenia skutków ewentualnych ataków terrorystycznych przez aktywny udział w stabilizowaniu środowiska bezpieczeństwa w Europie i na świecie. W dzisiejszej Europie z zagrożeniem terrorystycznym kojarzy się głównie radykalizm islamski; w latach 70. i 80. natomiast dominował w Europie terroryzm separatystyczny i radykalnej lewicy. Wiele z ostatnich, najgłośniejszych ataków zostało przeprowadzonych przez osoby ze środowisk radykalnego Islamu lub należące do międzynarodowych organizacji terrorystycznych, np. ISIS.

1 https://www.europol.europa.eu/tesat/2017/1.1.TERRORIST_ATTACKS_AND_SUSPECTS_ARRESTED.html (dostęp: 17.11.2017).

2 B. Hall, ISIS. Państwo Islamskie, thum. P. Wolak, Warszawa 2015, s. 63.

3 M. Fleming, Terroryzm polityczny, „Wojskowy Przegląd Prawniczy” nr 1, Warszawa 1996, s. 18 . 
Starając się dokonać oceny ryzyka związanego z radykalizmem islamskim w naszym państwie, możemy określić, że jest ono wprawdzie niskie, ale nie zerowe. Polska znajduje się w odmiennej sytuacji niż kraje Europy Zachodniej. Społeczność muzułmańska w Polsce jest znacząco mniej liczna niż np. w Zachodniej i Północnej Europie. Doświadczenia z Europy Zachodniej pokazują również, że radykalizacja jest często związana ze zjawiskiem wykluczenia społecznego. Należałoby więc odpowiedzieć na pytanie, czy społeczność muzułmańska zamieszkująca nasz kraj jest pod względem kulturowym wystarczająco dobrze zintegrowana z resztą społeczeństwa i czy nie należy do grupy osób wykluczonych społecznie.

Pomimo małej liczby obywateli muzułmańskich zamieszkujących terytorium Polski wydaje się, iż należy brać pod uwagę zaangażowanie naszego państwa w globalną koalicję przeciwko ISIS, a to może stać się przyczyną ataku terrorystycznego. Terroryści mogą także koncentrować się na naszym kraju ze względu na luki w systemie bezpieczeństwa lub na atrakcyjność pewnych celów na terytorium Polski.

Choć prawdopodobieństwo ataku terrorystycznego na nasz kraj jest niskie, pomimo wskazanych aspektów, nie można wykluczyć radykalizacji pojedynczych osób lub małych grup zainspirowanych ideologią Islamu, które mogłyby podejmować działania bez więzi z organizacjami terrorystycznymi. $Z$ tego powodu ewentualny atak terrorystyczny na terytorium Polski miałby charakter działania raczej jednostki lub małej grupy i mógłby być inspirowany przez międzynarodowe grupy terrorystyczne, lecz bez bezpośredniego związku z nimi. Inicjatorem nie musi stać się islamski radykalizm - indywidualne motywy mogą opierać się na innej ideologii (przykład z niedawnej przeszłości: atak Andersa Breivika w Norwegii - Breivik jest prawicowym ekstremistą, który postrzega Islam jako zagrożenie). Radykalizacji mogą ulegać również osoby bez powiązań z konkretną społecznością - np. tzw. nawróceni, determinowani propagandą internetową ${ }^{4}$.

Priorytetem działań antyterrorystycznych powinno być zwalczanie rozprzestrzeniania nienawiści i radykalnych treści w mediach internetowych, głównie na portalach społecznościowych. Istotne jest również, aby monitorować aktywność wszystkich grup ekstremistycznych działających na terytorium naszego kraju, ponieważ nawet jeśli same nie prowadzą gwałtownych działań, mogą zachęcać osoby skłonne do realizowania radykalnych programów w praktyce. Znaczące ryzyko w tym zakresie dotyczy tzw. grup islamofobicznych, które szczególnie zwracają uwagę mediów, a w niektórych wypadkach również mają wsparcie polityczne. Takie zachowania mogą się przyczyniać do:

— poczucia wyobcowania i wykluczenia społecznego oraz późniejszej radykalizacji osób z szeregów muzułmańskiej mniejszości;

— budowania radykalnej bojowej retoryki i szerzenia strachu oraz wzrostu liczby zagrożeń, aby sprowokować indywidualne gwałtowne działania; celem jest członkostwo nowych osób w społeczności muzułmańskiej, a także poszukiwanie

${ }^{4}$ M. El Ghamari, Potencjalne zagrożenia bezpieczeństwa międzynarodowego, Warszawa 2016, s. 210. 
ich wśród elit politycznych i społecznych lub w społeczeństwie. Ataki niezależnie działających terrorystów, tzw. samotnych wilków, są bardzo trudne do zidentyfikowania i uniknięcia, więc oprócz zapobiegania radykalizacji należy uwzględnić również gotowość i zdolność do szybkiego reagowania przez ustawowo powołane formacje mundurowe, tak aby przygotować do działań antyterrorystycznych potencjalne cele lub złagodzić skutki powstałych incydentów.

Zjawisko działalności „zagranicznych bojowników” dotyczy cudzoziemców biorących udział w różnych konfliktach zbrojnych — np. w walkach na Ukrainie - a w ostatnim czasie również w konflikcie zbrojnym w Syrii i Iraku. W tym skomplikowanym konflikcie występuje wielu graczy i wiele grup, które działają w wymiarze międzynarodowym. Ta kłopotliwa sytuacja jest wykorzystywana przez niektóre organizacje terrorystyczne w celu kontrolowania dużej powierzchni terenu oraz dokonywania zakupu nowych urządzeń na potrzeby własnych działań. Dzięki wyrafinowanej propagandzie terroryści dokonują rekrutacji nowych zwolenników, zameldowanych w UE, zasilając potencjał bojowy organizacji terrorystycznych ${ }^{5}$. „Zagraniczni bojownicy” są poważnym problemem szczególnie dla krajów Europy Zachodniej - nowo zwerbowani, zradykalizowani obywatele po powrocie do ojczyzny mogą stanowić znaczne zagrożenie bezpieczeństwa: podczas pobytu w strefie konfliktu zyskują doświadczenie bojowe, a także wysoki stopień indoktrynacji ideologicznej i mogą próbować przeprowadzić działania na terytorium Europy. Chociaż jest to w dużej mierze problem europejski, Polska nie należy do krajów znacząco dotkniętych tym zjawiskiem.

\section{Zagrożenie atakami terrorystycznymi na infrastrukturę krytyczną}

Ochrona infrastruktury krytycznej jest jednym z najważniejszych zadań każdego kraju. W aspekcie prawnym zagadnienia ochrony infrastruktury krytycznej zostały ujęte w ustawie o zarządzaniu kryzysowym. Dla organizacji terrorystycznych infrastruktura krytyczna może stanowić cel działań, ponieważ atak w tej sferze może spowodować poważne obrażenia, w tym zagrożenie życia i zdrowia wielu osób - terroryzm działa głównie w aspekcie psychologicznym poprzez prowadzenie ataków z uwzględnieniem obiektywnych konsekwencji. Zasadniczym celem terrorystów jest wpływanie na opinię publiczną i szerzenie w społeczeństwie poczucia strachu i paniki. Dlatego też należy uwzględnić fakt, że np.

5 „Sześć osób oskarżonych o powiązania z tzw. Państwem Islamskim zostało aresztowanych w Hiszpanii, Wielkiej Brytanii i Niemczech — powiedział w środę 28.06.2017 minister spraw wewnętrznych Hiszpanii Juan Ignacio Zoido Álvarez. Oskarżeni mieli werbować nowych członków organizacji i wysyłać ich do stref konfliktowych". Radykalizowali i werbowali bojowników. Aresztowano cztery osoby, http://www.tvn24.pl/wiadomosci-ze-swiata,2/hiszpania-aresztowano-szescosob-oskarzonych-o-powiazania-z-is, 752498.html (dostęp: 29.06.2017). 
rozległa awaria zasilania może ostatecznie spowodować znacznie większe szkody i skutkować liczniejszymi ofiarami niż atak zamachowca-samobójcy ${ }^{6}$. Dla przykładu możemy przyjąć wariant ataku w metrze, w którym dochodzi do pożaru traumatyczny efekt wywarty na populacji będzie bardzo duży. Atak na infrastrukturę krytyczną może stanowić okazję do spowodowania znaczących szkód przy stosunkowo niewielkim nakładzie sił i środków. Ochrona zasobów infrastruktury krytycznej zaś jest względnie kosztowna, a przez to trudna.

$\mathrm{W}$ ramach wskazania prawdopodobnych obiektów ataku w infrastrukturze krytycznej cele ataków możemy podzielić na:

- cele miękkie,

- cele twarde.

$\mathrm{C}$ e $1 \mathrm{e} \mathrm{m} \mathrm{i} \mathrm{ę} \mathrm{k} \mathrm{k} \mathrm{i} \mathrm{e} \mathrm{są} \mathrm{powszechnie} \mathrm{określane} \mathrm{jako} \mathrm{miejsca} \mathrm{o} \mathrm{wysokim}$ natężeniu obecności ludzi (np. centra handlowe, szpitale, obiekty transportu publicznego, obiekty sportowe, szkoły, różne obiekty kulturalne). Ze względu na koszty finansowe cele miękkie nie są tak dobrze ochraniane, jak cele twarde. $\mathrm{C}$ e 1 e $\mathrm{tw}$ a $\mathrm{rd}$ e natomiast to lotniska, elektrownie jądrowe $\mathrm{i}$ inne obiekty strategicznego znaczenia $\mathrm{w}$ aspekcie funkcjonowania państwa. Niedawne doświadczenia potwierdzają, że terroryści koncentrują się na miękkich celach, przeprowadzając różnego rodzaju ataki. Takie działania mają znaczący wpływ psychologiczny przy niewielkich kosztach. Ostatnio natomiast przeprowadzono ataki w jednym czasie w kilku miejscach (Paryż, Bruksela) — ta strategia stawia wyższe wymagania dotyczące nakładów sił i środków bezpieczeństwa ${ }^{7}$.

Skoro cele miękkie są prawdopodobnie najbardziej narażone na ataki terrorystyczne, należy zwrócić szczególną uwagę na obiekty o wysokiej wartości symbolicznej. Do takich zalicza się miejsca związane z kultem religijnym, budynki ambasad, siedziby mediów, instytucje administracji publicznej czy siedziby partii politycznych.

\section{Analiza SWOT ${ }^{8}$}

Przy analizie zagadnienia terroryzmu bardzo ważnym czynnikiem jest jak najbardziej obiektywne, a nawet krytyczne, spojrzenie na możliwości jego oddzia-

${ }^{6}$ K. Rękawek, Zagraniczni bojownicy w Syrii i Iraku: skala problemu i zagrożenie dla Europy, „Biuletyn PISM” 2014, nr 110, s. 4.

7 https://www.europol.europa.eu/tesat/2017/1.1.TERRORIST_ATTACKS_AND_ SUSPECTS_ARRESTED.html (dostęp: 17.11.2017).

8 SWOT: Strengths (mocne strony organizacji), Weaknesses (słabe strony organizacji), Opportunities (szanse w otoczeniu), Threats (zagrożenia w otoczeniu). To kompleksowa metoda służąca do badania otoczenia organizacji oraz analizy jej wnętrza; zaliczana jest do metod analizy strategicznej, służy do oceny pozycji strategicznej organizacji. To propozycja systematycznej i wszechstronnej oceny zewnętrznych i wewnętrznych czynników określających kondycję bieżącą i potencjał rozwojowy organizacji. 
ływania w aspekcie bezpieczeństwa państwa — następująca analiza SWOT stanowi narzędzie tej oceny.

Mocne strony:

— niewielki odsetek społeczności muzułmańskiej zamieszkującej w naszym państwie;

— niska atrakcyjność państwa dla działań międzynarodowych grup terrorystycznych w zakresie organizowania ataków terrorystycznych;

- dostosowane przepisy prawa w zakresie walki z terroryzmem;

- dobrze funkcjonujący zintegrowany system ratownictwa, który w przypadku ataku terrorystycznego jest w stanie sprostać skali ewentualnych skutków; Polski;

— oddziaływanie fali migracji do Europy ma jedynie charakter pośredni dla

— wymiana informacji oraz współpraca międzynarodowa policji i służb wywiadowczych.

Stabe strony:

— brak doświadczeń w kwestii ataków terrorystycznych w naszym państwie;

- ograniczona zdolność Polski w zakresie wpływania na rozwój wydarzeń poza UE, które determinują ryzyko szerzenia terroryzmu i destabilizację Bliskiego Wschodu;

- reputacja Polski jako kraju islamofobicznego, zbudowana m.in. przez wypowiedzi niektórych polityków, które są nagłaśniane na Bliskim Wschodzie i Afryce Północnej;

— słaba przewidywalność ataków terrorystycznych spowodowana działaniami niezależnymi od zagranicznych partnerów;

— ograniczone środki finansowe na zapobieganie zagrożeniom terrorystycznym;

— niedostateczny poziom wdrażania nowoczesnych technologii służących zapewnieniu porządku i bezpieczeństwa publicznego.

Szanse:

— możliwość czerpania z doświadczeń krajów zachodnich w ramach działań antyterrorystycznych;

— doskonalenie systemu ochrony infrastruktury krytycznej;

— zapobieganie radykalizacji i wykluczeniu społecznemu osób zagrożonych radykalizacją;

— działania czynników zewnętrznych w stabilizacji sytuacji w Iraku, w Syrii, w Libii oraz działania przeciwko ISIS;

— kontrola przepływów finansowych, które wspierają grupy terrorystyczne. 
Zagrożenia:

— samodzielne działania terrorystów (,samotne wilki”);

— ataki na cele miękkie infrastruktury krytycznej;

- wzrost populizmu i ksenofobii w wyniku ataków terrorystycznych;

— przepływ migracyjny oraz działania radykalnych organizacji, które mogą prowadzić do brutalnego ekstremizmu;

— zagrożenie polskich obywateli poza granicami państwa;

— groźba finansowania terroryzmu i innych działań wspierających terroryzm;

— radykalizm islamski;

— ekstremizm polityczny i obecność innych organizacji terrorystycznych;

— kryzys migracyjny.

\section{Podsumowanie}

W problematyce terroryzmu kluczową rolę odgrywa profilaktyka w zapobieganiu zagrożeń. To właśnie ten aspekt wpisuje się w kompetencje służb wywiadowczych i innych sił bezpieczeństwa. Jednym z podstawowych warunków skutecznej walki z terroryzmem jest zdolność pozyskiwania aktualnych informacji na temat organizacji terrorystycznych, ich finansowania i działania. Niezbędna w tym aspekcie wydaje się współpraca społeczeństwa ze służbami wyznaczonymi do zwalczania zagrożeń terrorystycznych. Metody walki z terroryzmem wciąż ulegają rozwojowi wskutek pojawiania się nowych trendów oraz sposobów prowadzenia działań przez terrorystów. Nikt dzisiaj nie odważy się wygłosić słów, że wojna $\mathrm{z}$ terroryzmem zmierza ku końcowi. Pewne rozwiązania uznawane za skuteczne dzisiaj mogą być nieaktualne jutro.

Chcąc utrzymać odpowiedni poziom bezpieczeństwa społeczeństwa, musimy analizować spektrum zagrożeń, przed którymi stoi nasz kontynent. Zewnętrzne warunki bezpieczeństwa $\mathrm{w}$ aspekcie terroryzmu dotyczą kwestii takich, jak ekstremizm i radykalizm oraz powiązana z nimi przestępczość zorganizowana. Ocena zagrożeń nie powinna dotyczyć jedynie ich identyfikacji - musi przewidywać również ich skutki uboczne, ponieważ znacząco wpływają one na obniżenie poziomu bezpieczeństwa. Jednakowoż wpływ dokonanych ataków terrorystycznych na bezpieczeństwo jest mniejszy niż całe spektrum przestępstw popełnionych w ciągu jednego roku w Unii Europejskiej i stanowi zaledwie ułamek ogólnej liczby ofiar, które są dotknięte potencjalnymi atakami terrorystycznymi. Terroryzm jest zjawiskiem, które może wstrząsnąć każdym państwem, również Polską. Ataki lub próby ataków, które miały miejsce w Europie lub gdziekolwiek indziej na świecie, są ostrzeżeniem dla tych państw, które jeszcze ich nie doświadczyły.

W budowaniu strategii antyterrorystycznych należy zwrócić uwagę na propagandę i ideologię, które często są istotnym filarem działań terrorystycznych. Cytowany już Jan Paweł II ubrał tę konieczność w następujące słowa: 
Nawet gdy jako motywację tej nieludzkiej praktyki podaje się jaką́ ideologię czy dążenie do stworzenia lepszego świata, akty terroryzmu nigdy nie mogą być usprawiedliwione. Tym bardziej, gdy — jak to się dzisiaj zdarza — te decyzje i akty przybierające niekiedy rozmiary prawdziwej masakry, porywanie osób niewinnych i niezamieszanych w konflikty, mają na celu propagandę własnej sprawy albo też, co gorsze, są celem samym w sobie, gdy zabija się tylko dla zabijania ${ }^{9}$.

\title{
Bibliografia
}

Bezpieczeństwo personalne a bezpieczeństwo strukturalne państwa, red. T. Grabińska, H. Spustek, Wrocław 2013.

Dukiewicz T., Information used by military coalition groups for minimalize terrorism threat, Międzynarodowa konferencja, Brno 29-30 października 2008 r. Taktika 2008, s. 83-88.

Fleming M., Terroryzm polityczny, „Wojskowy Przegląd Prawniczy” nr 1, Warszawa 1996.

Ghamari M. El, Potencjalne zagrożenia bezpieczeństwa międzynarodowego, Warszawa 2016.

Hall B., ISIS. Państwo Islamskie, tłum. P. Wolak, Warszawa 2015.

Hill Ch., Smith M., Vanhoonacker S., International Relations and the European Union, Oxford 2017. http://www.europol.europa.eu/tesat/2017/1.1.TERRORIST_ATTACKS_AND_SUSPECTS_ARRESTED.html.

http://www.tvn24.pl/wiadomosci-ze-swiata,2/hiszpania-aresztowano-szesc-osob-oskarzonych-opowiazania-z-is, $752498 . \mathrm{html}$.

Liedel K., Zwalczanie terroryzmu międzynarodowego w polskiej polityce bezpieczeństwa, Warszawa 2010.

Radykalizowali i werbowali bojowników. Aresztowano cztery osoby, http://www.tvn24.pl/wiadomosci-ze-swiata, 2/hiszpania-aresztowano-szesc-osob-oskarzonych-o-powiazania-z-is, 752498. html (dostęp: 29.06.2017).

Rękawek K., Zagraniczni bojownicy w Syrii i Iraku: skala problemu i zagrożenie dla Europy, „Biuletyn PISM" 2014, nr 110.

Zgryziewicz R., Strategia komunikacyjna Daesh zagrożeniem dla wspótczesnej Europy, „e-Politikon" 2016, nr XX.

\section{TERRORISM IN THE FACE OF STATE SECURITY}

\section{Summary}

The article focuses on the issue of the threat of terrorism. Terrorism plays a vital role in the environment, gradually becoming a major threat to any conflict affecting the functioning of the state. Experience has shown that in the fight against terrorism, the key to victory is the exchange of intelligence and new techniques and procedures for action. Anti-terrorism methods are continually evolving as a result of new trends and ways in which terrorist activities are carried out.

Keywords: terrorism, international security, security threats, security environment

\author{
Tomasz Dukiewicz \\ tomduki@wp.pl
}

9 Jan Paweł II, Encyklika Sollicitudo Rei Socialis. 